Maciej BĄK

Uniwersytet im. Adama Mickiewicza w Poznaniu

\title{
TRÓJKĄT WEIMARSKI W LATACH 1991-1999 I JEGO ZNACZENIE DLA BEZPIECZEŃSTWA EUROPEJSKIEGO
}

Celem niniejszego opracowania jest syntetyczne przedstawienie wpływu Trójkąta Weimarskiego na bezpieczeństwo europejskie. Przyjęta w artykule cezura czasowa stanowi odzwierciedlenie dwóch wydarzeń: podpisanie Deklaracji Weimarskiej oraz wstąpienie Polski w struktury Paktu Północnoatlantyckiego. Państwa należące do Trójkąta Weimarskiego zajmują centralne miejsce w Europie, które ze względu na specyfikę geograficzną, historyczną i polityczną miały kluczowe znaczenie dla budowania nowej świadomości i nowej współpracy w Europie (Genscher, 1995: 895).

Istotne z punktu widzenia przedstawianej problematyki wydaje się uwzględnienie przede wszystkim relacji polsko-niemieckich, które posiadały kluczowe znaczenie dla układu geostrategicznego i geopolitycznego w kontekście europejskim oraz regionalnym. Przeszłość w relacjach pomiędzy Polską a Niemcami przeplatała się okresami napięć, wrogości oraz współpracy służącej interesom społeczności obu państw (Europa, 2002: 46; Koszel, 1999). To w interesie zarówno Niemiec, jak i Polski leżało włączenie państw postkomunistycznych do europejskich procesów integracyjnych oraz utrzymanie ładu polityczno-militarnego, ponieważ tylko w ten sposób można było doprowadzić do wzrostu bezpieczeństwa na kontynencie europejskim (Michałowski, 1998: 24). Zarówno Polska, jak i Niemcy mogły stać się przykładem, jak przezwyciężyć różnice w poziomie dobrobytu, techniczno-cywilizacyjną przepaść i społeczno-kulturowe wyobcowanie, a co najważniejsze zapewnić pokój i stabilizację w Europie (Bingen, 1992: 39).

Sytuacja, jaka miała miejsce w Europie na początku lat dziewięćdziesiątych, niosła ze sobą również wiele wątpliwości i pytań, m.in.: Jaki wpływ na bezpieczeństwo w Europie miały stosunki polsko-niemieckie? Jaką rolę w tej dziedzinie odegrał Trójkąt Weimarski?

Fundamentalne zmiany, które dokonały się w państwach Europy Środkowej i Wschodniej w latach 1989-1991 doprowadziły do uzyskania przez państwa należące do tej części kontynentu politycznej niezależności i suwerenności. Dawało to ogromne możliwości do przeprowadzenia wewnętrznej transformacji ustrojowo-gospodarczej, jak również stwarzało warunki do nowego ułożenia stosunków między państwami byłego bloku wschodniego. Zaistniała sytuacja dawała także szanse na innowacyjne spojrzenie oraz ułożenie wzajemnych, partnerskich stosunków pomiędzy państwami postkomunistycznymi a państwami zachodnimi (Wojsko Polskie, 1995: 9). Miejsce, w jakim znalazła się Polska po 1989 r., wyznaczało szanse na zajęcie od- 
powiedniej do posiadanych możliwości, pozycji i roli w świecie postzimnowojennym (Bieleń, 1993: 37).

Charakterystycznym aspektem sytuacji bezpieczeństwa Polski i pozostałych państw postkomunistycznych w tym okresie był brak inherencji do tak zwanego "twardego" systemu bezpieczeństwa (Kuźniar, 2001: 62-65). Głównym celem polityki zagranicznej państw Europy Środkowo-Wschodniej było więc przekonanie Zachodu, iż bez zaspokojenia usprawiedliwionych interesów bezpieczeństwa Polski i innych państw położonych między Rosją a Niemcami, stabilizacji w tej części Europy nie będzie (Żurawski vel Grajewski, 1996: 83).

Najtrudniejszym procesem okazał się demontaż więzów i zależności wynikających z przynależności do bloku komunistycznego. Pierwszą istotną zmianą w tym zakresie było podjęcie kroków zmierzających do rozpadu Układu Warszawskiego i Rady Wzajemnej Pomocy Gospodarczej. Zapoczątkowanie działań na rzecz budowy gospodarki rynkowej, w tym rozliczeń dolarowych między państwami, doprowadziło w 1991 roku do rozwiązania działającej od 1949 r. Rady Wzajemnej Pomocy Gospodarczej (Wojsko Polskie, 1995: 9). Natomiast likwidacja Układu Warszawskiego przebiegła niespodziewanie szybko. Realizowano ten proces w dwóch etapach. Na początku lutego $1991 \mathrm{r}$. rozwiązano struktury wojskowe organizacji, następnie zaś w lipcu 1991 r., na posiedzeniu Doradczego Komitetu Politycznego Układu Warszawskiego zadecydowano o całkowitej likwidacji układu (Otłowski, 2002: 23-26).

Rozwiązanie Paktu Warszawskiego oraz trudna sytuacja w Związku Radzieckim, doprowadziły do przyspieszenia przez rząd polski starań o porozumienie w sprawie wycofania żołnierzy rosyjskich z terytorium Polski. Udało się to dopiero po trzynastu rundach rokowań (Tabor, 1992: 150-151). Porozumienie zostało ostatecznie podpisane i przyjęte przez prezydentów Polski i Rosji 22 maja 1992 r. Wydarzenia te spowodowały konieczność opracowania nowych zasad polityki w zakresie bezpieczeństwa i obronności.

Polska nie mogła długo pozostać w „próżni bezpieczeństwa”, która powstała na skutek rozwiązania paktu militarnego (Kwaśniewski, 2000: 218). Od początku transformacji systemowej poszukiwano rozwiązań problemu bezpieczeństwa, które ukazywały różne koncepcje, opcje i modele. Ścierały się ze sobą sprzeczne w zasadzie założenia przewidujące między innymi samodzielność obronną, budowanie systemu bezpieczeństwa w ramach konfederacji środkowoeuropejskiej, a także najbardziej atrakcyjną z opcji, czyli przystapienie do struktur euroatlantyckich (Koziej, 1991). Należy zauważyć, że tempo w tym zakresie było odpowiednie do realnych możliwości, jakie pojawiły się w rezultacie ewolucji sytuacji międzynarodowej, zmian wewnętrznych w kraju oraz stopniowego odrzucania innych opcji w sferze bezpieczeństwa. Trzeba w tym miejscu przypomnieć o ostrożności Zachodu, o prognozach reakcji Rosji oraz o częstych zmianach politycznych na początku lat dziewięćdziesiątych (Bieleń, 1992: 77-78).

Sytuacja w jakiej znalazło się polskie społeczeństwo po 1989 r. wywołała poczucie zawieszenia, połączone z uczuciem strachu i brakiem pewności (Najdowski, 1991: 7-8). Rozpad Związku Radzieckiego, jak również traktat z Niemcami (Traktat, 1992), spowodował, że już w następnym roku odsetek dostrzegających zagrożenie w odniesieniu do aktualnej sytuacji międzynarodowej dla niepodległości kraju spadł radykalnie z 44 do 28\% (Od Uktadu, 2001: 168-169). 
Mając na uwadze cele polskiej polityki europejskiej należy jednoznacznie stwierdzić, że znaczącym wydarzeniem w dziedzinie bezpieczeństwa europejskiego było powstanie zjednoczonego państwa niemieckiego. Warto w tym miejscu przypomnieć, że polska polityka zagraniczna $\mathrm{w}$ tym czasie odegrała zasadniczą rolę $\mathrm{w}$ zjednoczeniu Niemiec (Fiszer, 1992: 25-26). Niemcy przestały być państwem frontowym wzdłuż „żelaznej kurtyny”, ich terytorium nie leżało już w zasięgu strategicznej ofensywy lub przeciwuderzenia wojsk Układu Warszawskiego i NATO, a na mapach wojskowych planistów przestały być zaznaczane jako obszar dogodny dla przeprowadzenia rozstrzygającego starcia między dwoma blokami wojskowymi (Solak, 1996: 117). Wszystko to sprawiało, że nowe Niemcy na nowo musiały odnaleźć odpowiednią do swoich możliwości i ambicji rolę w środowisku międzynarodowym.

Od tego momentu Polska znajdowała się na wschodnim „przedmurzu” zachodnich struktur wielonarodowych, mianowicie Unii Europejskiej i NATO (Latawski, 1993: 72). Niemcy, które po 1990 r. umocniły swoją pozycję polityczną i ekonomiczną w Unii Europejskiej, jak również zostały uznane za mocarstwo regionalne i głównego sojusznika Stanów Zjednoczonych (Niemcy, 1995: 69; Malinowski, 2009: 103-119; Kiwerska, 2011: 137-142), w pełni popierały polskie dążenia do integracji ze strukturami polityczno-wojskowymi i gospodarczymi Europy Zachodniej, stając się tym samym rzecznikiem polskich interesów (Malinowski, 1997: 295; Stosunki, 2007: 234-241).

Zjednoczenie Niemiec stanowiło także ważny aspekt w kwestii prawno-międzynarodowego uregulowania zachodnich granic Polski. Regulacja w tej kwestii została dokonana dwutorowo: najpierw w Uktadzie o końcowej regulacji $w$ odniesieniu do Niemiec (Układ „2+4”), gdzie określono obszar nowych zjednoczonych Niemiec, następnie w dwustronnym układzie polsko-niemieckim z 14 listopada 1990 r. o ostatecznym uznaniu przez RFN granicy na Odrze i Nysie (Otłowski, 2002: 17; Barcz, 1994; Muszyński, 1991: 108). Ponadto jego uzupełnieniem był podpisany 17 czerwca $1991 \mathrm{r}$. w Bonn przez Polskę i Niemcy traktat o przyjaźni i współpracy (Traktat, 1992).

Wraz z traktatem o dobrym sąsiedztwie i przyjaznej współpracy zostały podpisane trzy inne ważne porozumienia, a mianowicie umowa międzyrządowa o polsko-niemieckiej współpracy młodzieży, umowa międzyrządowa o utworzeniu Polsko-Niemieckiej Rady Ochrony Środowiska oraz umowa o utworzeniu Polsko-Niemieckiej Komisji Międzyrządowej do spraw Współpracy Regionalnej i Przygranicznej. Umowy te są pierwszymi aktami bilateralnymi, wynikającymi z traktatu z 17 czerwca $1991 \mathrm{r}$. i traktat ten konkretyzującymi (Podstawy, 1992: 61).

Umowy te uznać należy jako początek budowy polsko-niemieckiej drogi pojednania i wspólnoty interesów, bowiem umożliwiły nawiązywanie bezpośrednich kontaktów pomiędzy tymi państwami, jak również stworzyły formalno-prawne podstawy rozwoju współpracy (Fiszer, 1996: 144).

Zbliżenie wspólnych interesów Niemiec i Francji, w ramach procesu integracji europejskiej, a także dążenie do wspólnego koordynowania wschodniej polityki Wspólnoty Europejskiej, było szansą dla państw Europy Środkowej i Wschodniej by spełnić swoje zachodnio-strukturalne ambicje. Pierwszym przejawem tak określonych celów obu państw było spotkanie francuskich i niemieckich ambasadorów, pełniących swoje funkcje w państwach Europy Środkowo-Wschodniej. W wydanej z okazji konsultacji 
w Weimarze tzw. Deklaracji Weimarskiej z 16-17 maja 1991 r. ${ }^{1}$ (Wyligała, 2010: 476-477) ambasadorowie obu państw pozytywnie odnieśli się do perspektywy przystąpienia nowych państw do Wspólnoty Europejskiej. Wyrażono konieczność wsparcia przez Francję i Niemcy procesu reform w państwach Europy Środkowo-Wschodniej. Ponadto Francja i Niemcy miały być gotowe do przyjęcia na siebie odpowiedzialności za pokój i stabilizację w Europie (ibidem: 121-122).

Następstwem tych wydarzeń było spotkanie ministrów spraw zagranicznych Francji, Niemiec i Polski w Weimarze, odbywające się 28-29 sierpnia 1991 r. Podsumowaniem spotkania było Wspólne oświadczenie w sprawie przyszłości Europy, znane również pod nazwą Deklaracji Weimarskiej. Dokument ten stał się podstawą działania Trójkąta Weimarskiego, który wedle prawa międzynarodowego nie był organizacją, lecz forum wymiany poglądów dotyczących najważniejszych kwestii polityki międzynarodowej (Koszel, 2006: 16-17).

Głównym celem Weimarskiego porozumienia było zapewnienie bezpieczeństwa i stabilności w Europie, jak również ułatwienie państwom Europy Środkowej i Wschodniej przystapienia do zachodnich struktur. Wskazywano w nim na dużą rolę Unii Zachodnioeuropejskiej i Sojuszu Północnoatlantyckiego. Deklaracja zawierała również niemieckie i francuskie wsparcie Polski w dążeniu do zbliżenia do Wspólnoty Europejskiej. Formuła politycznej i polityczno-wojskowej współpracy trójstronnej z Francją i Niemcami była cenna dla Polski, gdyż stanowiła jeden z ważnych instrumentów realizacji priorytetów polskiej polityki zagranicznej i bezpieczeństwa. Z kolei dla Niemiec i Francji Trójkąt Weimarski był przykładem dążenia do tworzenia nowych konstrukcji przezwyciężających stare podziały. Ta forma współpracy państw należących do Unii Europejskiej z Polską stanowi symbol pojednania trzech wielkich narodów europejskich, którego celem było spowodowanie by dawny obszar wielkich wojen europejskich przekształcił się w filar bezpieczeństwa kontynentu (Przemówienie, 2007: 366-379).

Zaproszenie Polski do Trójkąta Weimarskiego należy uznać za wyraz przekonania zachodnich partnerów o tym, że Polska jest w stanie odegrać znaczącą rolę w procesie zjednoczenia Europy i budowy bezpieczeństwa europejskiego (Parzymies, 1994: 246).

Współpracę obronną z Niemcami i Francją Polska nawiązała na początku lat dziewięćdziesiątych ${ }^{2}$. Oficjalne kontakty pomiędzy resortami obrony Polski i Niemiec oraz siłami zbrojnymi obu państw nawiązano w pierwszej połowie 1990 r. $^{3}$ (Koszel, 2006: 46). Bilateralne porozumienie o współpracy wojskowej między Polską a Republiką Francuską zawarto w czerwcu $1992 \mathrm{r}$. Ich uwieńczeniem było podpisanie 25 stycznia 1993 r. przez ministrów obrony Janusza Onyszkiewicza i Volkera Rühe resortowej

1 Une nouvelle architecture pour l'Europe - releve de conclusions de la conference des ambassadeurs Francais et Allemands tenue a Weimar les 16 et 17 Mai 1991 (Déklaration de Weimar).

2 Inicjatywa współpracy wojskowej w 1990 roku wyszła od strony niemieckiej. Na uwage zasługuje również fakt, iż Polska jako ostatnie państwo Paktu Warszawskiego otworzyło ataszat wojskowy w RFN.

3 Oficjalne rozmowy zapoczątkowane zostały wizytą wiceministra obrony RFN Agnes Hürland-Büning w maju 1990 roku w Warszawie. W jej następstwie odbyło się wiele wzajemnych wizyt ministrów, szefów sztabów, dowódców rodzajów sił zbrojnych, grup specjalistycznych. 
Umowy o współpracy wojskowej ${ }^{4}$. Dokument ten uściślał wojskowe partnerstwo między państwami oraz był aktem umożliwiającym zawieranie późniejszych umów dwustronnych przez poszczególne formacje sił zbrojnych.

W 1992 r., zgodnie z „Założeniami polskiej polityki bezpieczeństwa” i „Strategią obronną Rzeczypospolitej Polskiej” priorytetem polityki zagranicznej RP był rozwój i umacnianie powiązań z wielostronnymi instytucjami zachodnioeuropejskimi oraz naszymi partnerami zachodnimi. Istotą tych działań było zapewnienie Polsce bezpieczeństwa oraz warunków przebudowy i rozwoju. Wybór ten znalazł odzwierciedlenie nie tylko w konsensusie głównych instytucjonalnych aktorów polskiej sceny politycznej, ale co najważniejsze, znalazł akceptację ze strony społeczeństwa (Kupiecki, 1998: 227-238).

Okazją do wymiany poglądów na temat kształtu europejskiej architektury bezpieczeństwa było drugie spotkanie w ramach Trójkąta Weimarskiego, które odbyło się w Bergerac 24 kwietnia 1992 r. Uznano, że Konferencja Bezpieczeństwa i Współpracy w Europie (KBWE) jest ważnym forum dyskusji o bezpieczeństwie na kontynencie europejskim. Przedstawiona została idea zawarcia, w ramach KBWE, traktatu o bezpieczeństwie w Europie. W związku z deklaracją Rządu RP, iż pełne członkostwo w NATO jest strategicznym celem Polski, wskazywano, że droga do Sojuszu będzie celem długotrwałym i osiąganym stopniowo. Podczas spotkania omówiono również sytuację w Bośni i Hercegowinie, Afganistanie i Górnym Karabachu. Ministrowie zaprezentowali wspólne stanowisko na temat konfliktów rozgrywających się na tych obszarach, potępiając rozwiązywanie ich za pomocą konfrontacji zbrojnej (Wspólna deklaracja, 1992).

Trzecie spotkanie ministrów spraw zagranicznych Trójkąta Weimarskiego odbyło się 11 i 12 listopada 1993 r. w Warszawie. Rozmowy dotyczyły m.in. problemów integracji europejskiej, zbliżenia Polski do struktur zachodnioeuropejskich i euroatlantyckich oraz budowy w Europie strefy stabilizacji i bezpieczeństwa. Najistotniejszym dokonaniem spotkania było uzgodnienie i wystapienie $\mathrm{z}$ inicjatywą przyznania Polsce statusu państwa stowarzyszonego z Unią Zachodnioeuropejską. Francja i Niemcy potwierdziły w ten sposób faktyczne poparcie dla Polski w procesie ściślejszego związania z europejskimi i euroatlantyckimi strukturami bezpieczeństwa. Wskazano na konieczność połączenia wysiłków państw Trójkąta Weimarskiego dla uczynienia z KBWE skuteczniejszego instrumentu dyplomacji prewencyjnej i pokojowego rozstrzygania konfliktów. Po raz pierwszy ministrowie poparli intensyfikację kontaktów wojskowych i współpracę między siłami zbrojnymi trzech państw, a także między Polską i Eurokorpusem (Wspólna deklaracja, 1993).

Zapoczątkowana przez ministrów spraw zagranicznych trzech państw współpraca w ramach Trójkąta Weimarskiego, poszerzona została 3 marca 1994 r. o aspekty współpracy polityczno-wojskowej i obronnej ${ }^{5}$. Stało się to możliwe dzięki równo-

4 Vereinbarung zwischen dem Bundesminister der Verteidigung der Bundesrepublik Deutschland und dem Minister für nationale Verteidigung der Republik Polen über die Zusammenarbeit im militärischen Bereich von 25. Januar 1993. Ponadto 31 marca 1995 r. podpisano Protokół dodatkowy o współpracy wojskowych służb kartograficznych. w Bonn.

Spotkanie ekspertów mające na celu konkretyzację współpracy odbyło się 10 czerwca 1994 r. 
ległemu rozbudowaniu kontaktów bilateralnych między Wojskiem Polskim i Bundeswehrą. Dla strony polskiej najważniejszym celem wojskowej współpracy było poznanie organizacji, funkcjonowania, procedur dowodzenia $w$ siłach zbrojnych Niemiec i Francji w celu dostosowania Sił Zbrojnych RP do standardów NATO (Gryz, 2003: 70). Zapowiedziano również, iż w związku z intensywnym rozwojem bilateralnych kontaktów wojskowych będzie możliwe przeprowadzenie wspólnych ćwiczeń operacyjnych.

Po przystąpieniu Polski do Partnerstwa dla Pokoju (PdP) 2 lutego 1994 r., współpraca Wojska Polskiego i Bundeswehry zacieśniła się jeszcze bardziej. Pierwsze ćwiczenia w ramach PdP, pod kryptonimem „Cooperative Bridge” odbyły się od 12-16 września 1994 r. w Polsce na poligonie Biedrusko pod Poznaniem, z udziałem trzynastu państw partnerskich. Polegały one głównie na wykonywaniu podstawowych zadań w ramach operacji pokojowych (Foerster, Wroński, 1994; Perlez, 1994).

Natomiast pierwsze trójstronne ćwiczenia wojskowe rozpoczęły się 13 października 1994 r. na francuskim poligonie Larzac. W ćwiczeniach udział wzięło 100 żołnierzy ze Śląskiego Okręgu Wojskowego. Ćwiczenia miały znaczenie praktyczne - w sytuacji, kiedy oddziały różnych państw biorących udział w misjach pokojowych muszą ze sobą współdziałać, oraz znaczenie symboliczne - ukazywało ono polityczne przemiany w Europie oraz zbliżenie się Polski do Unii Europejskiej i Unii Zachodnioeuropejskiej (Manewry, 1994; Podwójne, 1994).

Podczas kolejnych konsultacji w ramach Trójkąta Weimarskiego w Bambergu 15 września 1994 roku oraz w Paryżu 26 październiku 1995 r. ustalono, że kooperacja w ramach UZE pozwala nawiązać treściwy dialog na temat problemów bezpieczeństwa $\mathrm{w}$ Europie i będzie stale rozwijana. Zwrócono uwagę również na fakt, iż współpraca w zakresie bezpieczeństwa umożliwiła Polsce, RFN i Francji przejście do zacieśnienia kontaktów wojskowych (Krzemień, 1994; Sołtyk, 1995).

Na uwagę zasługuje porozumienie podpisane 19 lipca 1995 r. przez dowódcę 4. Korpusu Lotniczego gen. dyw. pil. Franciszka Maciołę i dowódcę 3. Dywizji Lotniczej generała Jürgena Höche z Gatow. Objęła ona m.in. praktyki sztabowe, wymianę doświadczeń oraz udział w uroczystościach kulturalnych i sportowych. Umowa była częścią podpisanego wcześniej układu Partnerstwo dla Pokoju i porozumienia Czyste Niebo (Koszel, 1999: 167).

Kolejne ćwiczenia dowódczo-sztabowe oficerów francuskich, niemieckich i polskich w ramach „Partnerstwa dla pokoju” - Concordia '96 - odbyły się w Szklarskiej Porębie 15 października 1996 r. Tematem ćwiczeń było zaplanowanie wojskowej misji humanitarnej na podstawie map i dokumentów (Humanitarnie, 1996).

Szóste, doroczne spotkanie ministrów spraw zagranicznych trzech państw odbyło się 19 grudnia 1996 roku w Warszawie. W zakresie bezpieczeństwa omówiono kwestie rozszerzenia Sojuszu Północnoatlantyckiego, stosunki NATO-Rosja oraz rolę OBWE w europejskiej architekturze bezpieczeństwa.

Podczas spotkania w dniach 2-3 lutego 1997 r. w Warszawie, ministrowie obrony: Stanisław Dobrzański, Volker Rühe, Charles Millon, podpisali wspólną Inicjatywe dotyczqca intensyfikacji trójstronnej wspótpracy polityczno-wojskowej $i$ wojskowej. Stworzyła ona instytucjonalne fundamenty współpracy przez powołanie Wspólnej Wojskowej Grupy Koordynacyjnej, czuwającej nad przygotowaniem i realizacją planu 
kooperacji trzech państw (Inicjatywa, 1998). Omówiono także sprawy dotyczące bezpieczeństwa europejskiego w obliczu sytuacji w Jugosławii.

Na szczycie NATO w Madrycie (8-9 lipca 1997 r.), zgodnie z wcześniejszymi zapowiedziami Sojusz oficjalnie zaprosił Polskę (Uchwała, 1997), Czechy i Węgry do bezpośrednich rozmów akcesyjnych (Do NATO, 1997; Węglarczyk, 1997). W odpowiedzi na tę sytuację odbyło się kolejne spotkanie ministrów obrony Trójkąta Weimarskiego (2-3 listopada 1997 r. w Weimarze). Dotyczyło ono szczegółowych przygotowań Polski do wejścia do NATO, jak również resortowej współpracy trójstronnej. Ministrowie Niemiec i Francji zadeklarowali gotowość do intensywnego wspomagania Polski w jej zbliżeniu ze strukturami atlantyckimi (Wyligała, 2010: 227).

Warto zauważyć, że oprócz spotkań ministerialnych 14 października 1997 roku odbyły się konsultacje szefów sztabów generalnych państw należących do Trójkąta Weimarskiego. Ponadto we wrześniu polski okręt podwodny brał udział w zgrupowaniu okrętów francuskich i niemieckich na Bałtyku, a w dniach 4-13 listopada 1997 r. we Francji odbyły się kolejne trójstronne ćwiczenia „Concordia” (ibidem: 228).

Negocjacje Polski z NATO trwały do 27 listopada 1997 r. kiedy przebywający w Brukseli Jerzy Buzek otrzymał list od Sekretarza Generalnego NATO Javiera Solany. Zawierał on akceptację wszystkich państw członkowskich oraz deklarację, że negocjacje z Polską zostały zakończone. Oznaczało to gotowość stron do podpisania protokołu akcesyjnego. Następnego dnia rządy państw NATO zatwierdziły protokół o przystąpieniu Polski, Czech i Węgier do Sojuszu (Świetlicki, 1998: 66-67).

Siódmy szczyt Trójkąta Weimarskiego odbył się 19 listopada 1997 r. we Frankfurcie nad Odrą w atmosferze związanej głównie z członkostwem Polski w NATO. Wskazano wówczas rok 2000 jako możliwą datę wejścia Polski do struktur euroatlantyckich. Dominowały również tematy związane $\mathrm{z}$ architekturą bezpieczeństwa europejskiego i integracją na kontynencie (Kosman, 1999: 65).

Szefowie dyplomacji państw członkowskich NATO podpisali 16 grudnia $1997 \mathrm{r}$. w Brukseli protokoły o przystąpieniu Polski, Czech i Węgier do NATO (Lis, 1999: 325). Tym samym państwa te zyskały status nieformalnego członka Sojuszu (Bielecki, 1997).

Kolejne spotkanie w ramach Trójkąta Weimarskiego odbyło się na najwyższym szczeblu w Poznaniu 21 lutego 1998 r. Po raz kolejny na spotkaniu tym politycy wyrazili poparcie dla integracji Europy i polskich dążeń do struktur zachodnich (Krzemiński, Thadden, 1998). Ponadto współpraca wojskowa w tym okresie rozwijała się równie dynamicznie - w dniach 14-15 kwietnia 1998 r. doszło do spotkania szefów sztabów generalnych, a w 19-20 kwietnia 1998 r. do konsultacji ministrów obrony.

W obliczu przesądzonego już członkostwa Polski w NATO odbyło się 6 stycznia 1999 r. w Paryżu doroczne spotkanie Trójkąta Weimarskiego. Pojawiły się również nowe propozycje współpracy przemysłu lotniczego i zbrojeniowego. Z kolei na spotkaniu ministrów obrony, które odbyło się 12-13 lutego 1999 r. rozważano między innymi o koncepcji europejskiej strategii obronnej oraz kryzysie w Kosowie.

Pełnoprawnym członkiem Sojuszu Polska stała się dopiero 12 marca 1999 r., kiedy w auli Owalnej Biblioteki im. Prezydenta Harry’ego Trumana w Independence, ówczesna sekretarz stanu Madeleine Albright, otrzymała z rąk szefa polskiej dyplomacji Bronisława Geremka dokument ratyfikacyjny polskiego członkostwa w NATO, podpi- 
sany przez prezydenta i kontrasygnowany przez premiera (Darewicz, 1999; Baczyński, 1999; Węglarczyk, 1999). Uroczystość przyjęcia Polski wraz z Czechami i Węgrami do NATO, która uwieńczyła sukces polskiej dyplomacji odbyła się podczas szczytu w Waszyngtonie w dniach 23-25 kwietnia 1999 r. (Rocznik, 2000: 344).

Spotkanie ministrów obrony państw należących do Trójkąta Weimarskiego miało miejsce po przystapieniu Polski do Paktu Północnoatlantyckiego w dniach 26-27 maja 1999 r. na zamku w Hambach. Rozmowy dotyczyły kierunków polityki bezpieczeństwa i obrony w Europie, stosunków z Rosją i Ukraina, a także sytuacji na Bałkanach. W ramach współpracy w Trójkącie Weimarskim w 1999 r. odbyły się także ćwiczenia wojskowe Baltica - poświęcone poszukiwaniu i zwalczaniu min morskich oraz Baltsar - obejmujące procedury poszukiwawczo-ewakuacyjne na Bałtyku. Ponadto w tym samym roku, w listopadzie, w Żaganiu odbyły się ćwiczenia z serii Concordia, w których po raz pierwszy swój udział wzięli przedstawiciele sił zbrojnych Ukrainy ze sztabu batalionu polsko-ukraińskiego (Wyligała, 2010: 230-231).

Rozszerzenie NATO o Polskę, Czechy i Węgry było znaczącym wydarzeniem kształtującym bezpieczeństwo w całym regionie euroatlantyckim, bowiem całkowicie przekreślało możliwość powrotu jałtańskiego układu sił w Europie. Bez zaangażowania Niemiec i Francji w ramach Trójkąta Weimarskiego nie byłoby to możliwe. Obszar Europy Środkowo-Wschodniej od tego momentu stał się szczególnie ważnym elementem w poszerzaniu strefy stabilności na kontynencie europejskim (Fiszer, 2002: 26). Z kolei dla państw należących do Trójkąta Weimarskiego członkostwo Polski w Sojuszu sprawiało, że otworzyły się nowe perspektywy współpracy w ramach struktur europejskich i atlantyckich.

Oceniając współpracę w ramach Trójkąta Weimarskiego, nie sposób pominąć płaszczyzny, na której odnoszono największą aktywność i sukcesy, mianowicie współdziałanie w dziedzinie bezpieczeństwa oraz zacieśniania współpracy wojskowej. Bardzo istotnym elementem polsko-niemieckiej kooperacji wojskowej było rozszerzenie jej formy o coroczne programy dwustronne, przygotowywane i zatwierdzane na poziomie ministrów obrony obu państw. W ich skład wchodziły wspólne manewry, kontakty pomiędzy poszczególnymi jednostkami i formacjami wojskowymi. Współpracy tej towarzyszyły szczegółowe konsultacje ekspertów na temat logistyki, wyposażenia, roli sił zbrojnych w państwach demokratycznych. Istotnym aspektem tego współdziałania było kształcenie kadr i rozmowy specjalistów najważniejszych wojskowych szkół wyższych obu państw (hamburskiej Akademii Dowodzenia Bundeswehry i warszawskiej Akademii Obrony Narodowej). Oficerowie polscy mieli możliwość odbywania specjalistycznych kursów, szkoleń oraz praktyk w jednostkach Bundeswehry (Kosman, 1999: 68-69).

Zaprezentowane w niniejszym artykule zagadnienia dowodza, że kooperacja trzech państw europejskich była dla Polski ważnym czynnikiem odbudowy jej pozycji w Europie jako suwerennego i demokratycznego państwa, a także płaszczyzną współdziałania z głównymi aktorami europejskiej sceny politycznej. W sensie geostrategicznym udział Polski w tym porozumieniu oznaczał docenienie jej roli jako głównego partnera zarówno Niemiec, jak i Francji (Parzymies, 1996: 201-203).

Polska mając na uwadze doświadczenia okresu międzywojennego, z których wynikało, że powiązania sojusznicze nie stanowiły skutecznych gwarancji bezpieczeństwa 
(Bąk, 2011: 63-76) sceptycznie odnosiła się do możliwości znalezienia oparcia w zachodnioeuropejskiej strukturze bezpieczeństwa pozbawionej komponentu polityczno-wojskowej obecności USA. Przyjęta przez Polskę koncepcja integracji z Zachodem, w której brak jest rywalizacji transatlantyckiej oraz akceptującą dominującą pozycję USA, sprzyjać miała budowaniu kooperatywnego systemu bezpieczeństwa w Europie. Miało to wpływ na dokonany przez Polskę wybór umacniania bezpieczeństwa narodowego w ramach nowego systemu bezpieczeństwa w Europie. System ten oparty był na twardych (militarnych) gwarancjach bezpieczeństwa NATO, uzupełniany przez inne instrumenty, jakie stwarzał system współdziałających instytucji europejskich. W praktyce oznaczał, że najważniejszą instytucją bezpieczeństwa jest NATO, a pozostałe tj. Unia Europejska, OBWE, Rada Europy, ugrupowania subregionalne, pełnią rolę wspomagającą (Zięba, 2005: 102-103).

Takie postrzeganie przez Polskę kwestii bezpieczeństwa w Europie stanowiło o słabościach wzajemnej współpracy w ramach Trójkąta Weimarskiego. Przede wszystkim miało to wpływ na zróżnicowany stopień zainteresowania partnerów formą ich wzajemnej współpracy. Wzmocnienie Trójkąta nie nastapiło także w związku z poszukiwaniem przez Francję i Niemcy strategicznego partnera w Europie. We Francji zaobserwować można było zdystansowany stosunek do Trójkąta Weimarskiego. Podobnie w kręgach administracji rządowej w Niemczech zainteresowanie współpracą malało (Rezygnacja, 2009: 262). Obu państwom łatwiej było samodzielnie pogłębiać ich stosunki bilateralne niż wprowadzać do niego trzeciego gracza - Polskę. Stąd postulowane od wielu lat włączanie Polski do współpracy francusko-niemieckiej odbywa się w niewielkim stopniu, przede wszystkim w wymiarze wojskowym (Wyligała, 2010: 72).

Ujemną stroną współpracy weimarskiej był również brak wspólnego zaangażowania państw w tworzenie europejskich zdolności reagowania kryzysowego i integrowanie europejskiego przemysłu zbrojeniowego, jak również fakt, iż polskim siłom zbrojnym nie udało się nawiązać trwałych kontaktów z Eurokorpusem ${ }^{6}$ (Parzymies, 2004: 32,38).

Dalszą współpracę państw Trójkąta Weimarskiego w sferze bezpieczeństwa szczególnie utrudniło poparcie przez Polskę interwencji Stanów Zjednoczonych w Iraku. W miarę zbliżania się do członkostwa w Unii Europejskiej, Polska złagodziła swoją krytykę i niechęć wobec Europejskiej Polityki Bezpieczeństwa i Obrony UE (EPBiO). Zwrot intensyfikacji współpracy nastapił w roku 2006. Wynikało to z ewolucji polskiego stanowiska wobec Europejskiej Polityki Bezpieczeństwa i Obrony UE (obecnie Wspólna Polityka Bezpieczeństwa i Obrony) i poparcia przez Polskę europejskich dążeń integracyjnych w tym obszarze. Rzeczywistym wyrazem współpracy był wspólny udział Polski, Francji i Niemiec w unijnej misji wojskowej o charakterze humanitarnym w Demokratycznej Republice Konga (Jankowski, 2011: 132-133; Górka-Winter, 2006).

Przełom, jaki dokonał się w roku 1989 wraz z jego następstwami, przyczynił się do osłabienia podejrzliwości $\mathrm{w}$ stosunkach polsko-niemieckich oraz francusko-niemiec-

${ }^{6}$ Eurokorpus jest związkiem taktyczno-operacyjnym szybkiego reagowania z siedzibą w Strasburgu. Został powołany przez Niemcy i Francję 22 maja 1992 roku na mocy tak zwanego raportu La Rochelle. 
kich, a także do zarysowania wspólnoty interesów. Państwa Trójkąta powinny dążyć do utrwalenia tej sytuacji (Kranz, 1998: 28; Geremek, 1998: 3), a także dać przykład w jaki sposób zmniejszyć różnice w standardzie życia, zlikwidować lukę techniczno-cywilizacyjną oraz przyczynić się do przyspieszenia zjednoczenia Europy i zapewnienia jej trwałego pokoju.

Przyszłość w relacjach w ramach Trójkąta Weimarskiego należy dziś postrzegać w kategoriach historycznej szansy dla Polski, Niemiec i Francji, a także szansy w zakresie tworzenia i rozwoju EPBiO/WPBiO. Wspólna Polityka Zagraniczna i Bezpieczeństwa UE jest obszarem, gdzie Trójkąt Weimarski może wnieść cenny wkład przy dużym udziale Polski, zwłaszcza w tzw. polityce wschodniej UE. Współpracę dotyczącą Ukrainy można uznać za realny przykład skuteczności i możliwości działania Trójkąta w przyszłości (Łukaszewicz, 2006: 115-116). Na przyszłość dobrze rokuje ożywienie współpracy Polski z Eurokorpusem, które nastąpiło od 2008 r. Niewątpliwie wpłynie to pozytywnie na współpracę w ramach Trójkąta Weimarskiego i zaangażowanie Polski, Francji i Niemiec w kwestie bezpieczeństwa i stabilności w Europie ${ }^{7}$.

\section{Bibliografia}

Baczyński J. (1999), NATO, godzina zero, „Polityka” 1999.

Barcz J. (1994), Udziat Polski w konferencji ,2+4”: aspekty prawne i proceduralne, Warszawa.

Bąk M. (2011), Kwestia bezpieczeństwa II i III RP, w: Wokót dwóch dwudziestoleci. Prace studenckiego Koła Naukowego Historii Najnowszej WNPiD UAM, (red.) E. Lesiewicz, W. Mazurczak, Poznań.

Bielecki J. (1997), Przedostatni krok do sojuszu, „Rzeczpospolita”, 17.12.1997.

Bieleń S. (1993), Pozycja i role międzynawowe Polski w okresie transformacji, „Dziś”, nr 2.

Bieleń S. (1992), ZSRR - wielka niewiadoma, w: Krajobraz po transformacji. Środowisko międzynarodowe Polski lat '90, (red.) R. Kuźniar, Warszawa.

Bingen D. (1992), Niemcy i Polska w nowym porzqdku europejskim, „Przegląd Zachodni”, nr 2.

Darewicz K. (1999), Jesteśmy w NATO, jesteśmy w domu, „Rzeczpospolita”, 13.03.1999.

Fiszer J. (1995), Niemcy: racja stanu po zjednoczeniu, w: Racja stanu w dobie transformacji ładu europejskiego. Implikacje dla Polski, (red.) J. Stefanowicz, I. Grabowska-Lipińska, Warszawa.

Fiszer J. (1992), Proces jednoczenia Niemiec po ,,jesieni ludów 1989” i jego specyficzne cechy, Warszawa.

Fiszer J. (2002), Rozszerzenie NATO o Polskę, Czechy i Wegry oraz ich znaczenie dla partnerstwa transatlantyckiego, „Przegląd Politologiczny”, nr 4.

Fiszer J. (1996), Stosunki polsko-niemieckie po roku 1989, „Studia Polityczne”, nr 5.

Foerster A., Wroński P. (1994), Partnerstwo dla poznania się, „Gazeta Wyborcza”, 7.09.1994.

Genscher H. D. (1995), Erinnerungen, Berlin.

7 W następstwie systematycznego wzrostu polskiego zaangażowania w struktury wojskowe w Europie Prezes Rady Ministrów w styczniu 2008 r. wyraził zgodę na rozpoczęcie negocjacji mających na celu zmianę statusu Polski w Eurokorpusie z państwa wysyłającego na państwo ramowe (Framework Nation). 
Geremek B. (1998), Trójkąt Weimarski, „Przegląd Środkowoeuropejski”, nr 20-21.

Gołembski F. (2002), Europa Środkowa jako obszar współpracy polsko-niemieckiej, w: Wspótpraca wojskowa Polski i Niemiec w procesie umacniania bezpieczeństwa europejskiego, (red.) R. Tomaszewski, Toruń.

Górka-Winter B. (2006), Misja Unii Europejskiej w Demokratycznej Republice Konga (EUFOR RD Congo), „Biuletyn” (PISM), nr 44.

Gryz J. (2003), Wspótpraca wojskowa Polski, Francji i Niemiec, w: Polska-Niemcy. Partnerzy wnowej Europie, (red.) A. Podraza, Lublin.

Humanitarnie na mapach (1996), „Gazeta Wyborcza”, 15.10.1996.

Inicjatywa Ministrów Obrony Republiki Federalnej Niemiec, Republiki Francuskiej i Rzeczypospolitej Polskiej dotyczqca intensyfikacji trójstronnej wspótpracy polityczno-wojskowej $i$ wojskowej (1998), „Przegląd Środkowoeuropejski”, nr 20-21.

Janicki L. (1992), Podstawy prawne stosunków Polski ze zjednoczonymi Niemcami, w: Wokót traktatów Polska-Niemcy, (red.) J. Koprucka-Purolowa, K. Malinowski, L. Janicki, Poznań.

Jankowski D. (2011), Weimarski trójkąt bezpieczeństwa, „Bezpieczeństwo Narodowe”, nr 17.

Kiwerska J. (2011), Od asymetrii do zrównoważonego partnerstwa: relacje Stany Zjednoczone-Republika Federalna Niemiec, „Przegląd Strategiczny”, nr 1.

Kosman M. M. (1999), Polska w Trójkacie Weimarskim, „Przegląd Zachodni”, nr 3.

Koszel B. (1999), Die Außenpolitik der Volksrepublik Polen gegenüber der Bundesrepublik Deutschland 1949-1989, w: Erlebte Nachbarschaft: Aspekte der deutsch-polnischen Beziehungen im 20. Jahrhundert, (eds.) J. P. Barbian, M. Zybura, Harrassowitz Verlag.

Koszel B. (1999), Mitteleuropa rediviva? Europa Środkowa i Poludniowo-Wschodnia w polityce zjednoczonych Niemiec, Poznań.

Koszel B. (2009), Rezygnacja czy wzmocnienie wspótpracy trójstronnej? Droga od pogrzebu Trójkata Weimarskiego do jego rewitalizacji, w: Trójkąt Weimarski w Europie. Wspótpraca polsko-niemiecko-francuska. Powstanie-potencjat-perspektywy, (red.) K. H. Standke, Toruń

Koszel B. (2006), Trójkąt Weimarski. Geneza - działalność - perspektywy wspótpracy, Poznań.

Koszel B. (2007), Stosunki Polska-Niemcy a bezpieczeństwo europejskie, w: Polska-Niemcy 1945-2007. Od konfrontacji do wspótpracy i partnerstwa w Europie, (red.) W. M. Góralski, Warszawa.

Koziej S. (1991), O bezpieczeństwie kraju bez kamuflażu, „Polska Zbrojna”, nr 168.

Kranz J. (1998), Polska i Niemcy w Europie, „Sprawy Międzynarodowe”, nr 1.

Krzemień E. (1994), Okno na zachód, „Gazeta Wyborcza”, 16.09.1994.

Krzemiński A., Thadden von R. (1998), Wzór na trójkąt, „Polityka”, 28.02.1998.

Kupiecki R. (1998), Od Londynu do Waszyngtonu. NATO w latach dziewięćdziesiatych, Warszawa.

Kuźniar R. (2001), Polska polityka bezpieczeństwa 1989-2000, Warszawa.

Kwaśniewski A. (2000), Dom wszystkich Polska, Warszawa.

Latawski P. (1993), Droga Polski do NATO - problemy i perspektywy, „Sprawy Międzynarodowe”, $\mathrm{nr} 3$.

Lis T. (1999), Wielki finat: kulisy wstępowania Polski do NATO, Kraków.

Łukaszewicz M. (2006), Trójkąt Weimarski po 15 latach, „Bezpieczeństwo Narodowe”, nr 2.

Malinowski K. (1997), Polityka Republiki Federalnej Niemiec wobec Polski w latach 1982-1991, Poznań.

Malinowski K. (2009), Przemiany niemieckiej polityki bezpieczeństwa 1990-2005, Poznań.

Manewry we Francji (1994), „Gazeta Wyborcza”, 14.10.1994. 
Michałowski S. (1998), RFN wobec rozszerzenia Unii Europejskiej, „Sprawy Międzynarodowe”, nr 2.

Muszyński J. (1991), Polska w obliczu zjednoczenia Niemiec, „Przegląd Zachodni”, nr 1.

Najdowski J. (1991), Opinia Publiczna wobec uczestnictwa Polski w wybranych organizacjach międzynarodowych, Raport CBOS, Warszawa.

Nowak-Jeziorański J. (2006), Polska droga do NATO. Listy, dokumenty, publikacje, Wrocław.

Otłowski T. (2002), Polska w procesie integracji z NATO i Uniq Zachodnioeuropejska 1991-1998, Toruń.

Parzymies S. (1994), Przyjaźń z rozsqdku: Francja i Niemcy w nowej Europie, Warszawa.

Parzymies S. (1996), Stosunki francusko-niemieckie jako przyktad dla stosunków Polski i Niemiec, w: Niemcy-

Parzymies S. (2004), Trójkąt Weimarski w poszerzonej Unii Europejskiej, „Sprawy Międzynarodowe", $\mathrm{nr} 2$.

Perlez J. (1994), Biedrusko Journal; The Cold War Armies Meet, Just to Link Army, „The New York Times", 15.09.1994.

Podwójne znaczenie (1994), „Gazeta Wyborcza”, 21.10.1994.

Polska-Rosja. Bezpieczeństwo europejskie i wspótpraca społeczeństw, (red.) M. Dobroczyński, Warszawa.

Przemówienie ministra spraw zagranicznych RP Władysława Bartoszewskiego wygłoszone na specjalnej sesji Bundestagu i Bundesratu 28 kwietnia 1995 roku w Bonn (2007), w: Polska-Niemcy 1945-2007. Od konfrontacji do wspótpracy i partnerstwa w Europie, (red.) W. M. Góralski, Warszawa.

Rocznik Strategiczny 1999/2000. Przeglad sytuacji politycznej, gospodarczej i wojskowej w środowisku międzynarodowym Polski, (red.) E. Haliżak, R. Kuźniar, D. Popławski, H. Szlajfer, Warszawa.

Solak J. (1996), Polska w polityce bezpieczeństwa Republiki Federalnej Niemiec, „Przegląd Zachodni”, nr 3.

Sołtyk R. (1995), Rosja dzieli Trójkat??, „Gazeta Wyborcza”, 27.10.1995.

Strzeszewski M. (2001), Od Układu Warszawskiego do NATO. Poczucie bezpieczeństwa kraju w społecznej świadomości oraz opinie Polaków o najlepszym sposobie zapewniania bezpieczeństwa kraju, w: Socjologiczne aspekty bezpieczeństwa narodowego, (red.) J. Maciejewski, Wrocław.

Świetlicki B. (1998), Współpraca Polski z NATO, „Rocznik Polskiej Polityki Zagranicznej”.

Tabor M. (1992), Wojskowe aspekty środowiska międzynarodowego Polski, w: Krajobraz po transformacji. Środowisko międzynarodowe Polski lat '90, (red.) R. Kuźniar, Warszawa.

Traktat między Rzeczypospolita Polskq a Republikq Federalnq Niemiec o dobrym sqsiedztwie i przyjaznej wspótpracy (1991), Dz. U. 1992, Nr 14, poz. 56.

Traktat o dobrym sq̨iedztwie i wspólpracy między Rzeczpospolita Polskq a Republikq Federalnq Niemiec (1991), Dz. U. 1992, Nr 14 poz. 56.

Uchwała Sejmu Rzeczypospolitej Polskiej z dnia 1 sierpnia 1997 r. w sprawie zaproszenia Polski do rozmów o członkostwie w Sojuszu Pótnocnoatlantyckim (1997), Monitor Polski 1997, Nr 50, poz. 474.

Węglarczyk B. (1997), Do NATO trzech, „Gazeta Wyborcza”, 13.06.1997.

Węglarczyk B., Dzień Dobry w NATO, „Gazeta Wyborcza”, 13-14.03.1999.

Węglarczyk B. (1997), Jak zdobyliśmy Zachód. Polska do NATO, „Dodatek do Gazety Wyborczej”, 9.07.1997.

Wojsko Polskie. Informator 1995, (1995), Warszawa. 
Wspólna deklaracja ministrów spraw zagranicznych Francji, Polski i Niemiec, Bergerac 24 kwietnia 1992 (1992), „Zbiór dokumentów PISM”, nr 3.

Wspólna deklaracja ministrów spraw zagranicznych Francji, Polski i Niemiec, Warszawa 12 listopada 1993 (1993), „Zbiór dokumentów PISM”, nr 4.

Wspólne Oświadczenie ministrów spraw zagranicznych Francji, Niemiec i Polski w sprawie przyszłości Europy Vereinbarung zwischen dem Bundesminister der Verteidigung der Bundesrepublik Deutschland und dem Minister für nationale Verteidigung der Republik Polen über die Zusammenarbeit im militärischen Bereich von 25. Januar 1993.

Wyligała H. (2010), Trójkąt Weimarski po rozszerzeniu UE - niewykorzystany instrument polskiej polityki zagranicznej?, „Przegląd Politologiczny”, nr 4.

Wyligała H. (2010), Trójkąt Weimarski. Wspótpraca Polski, Francji i Niemiec w latach 1991-2004, Toruń.

Zięba R. (2005), Europejska polityka bezpieczeństwa i obrony, Warszawa.

Żurawski vel Grajewski P. (1996), O bezpieczeństwie Rzeczypospolitej, „Przegląd Zachodni”, nr 3.

\title{
STRESZCZENIE
}

W artykule przeanalizowano wpływ Trójkąta Weimarskiego na bezpieczeństwo europejskie. Głównym celem jest zwrócenie uwagi na stosunki polsko-niemieckie oraz francusko-niemieckie, które posiadały kluczowe znaczenie dla układu geostrategicznego i geopolitycznego w kontekście europejskim. Forma współpracy państw należących do Unii Europejskiej z Polską stanowi symbol pojednania trzech wielkich narodów europejskich, którego celem było spowodowanie by dawny obszar wielkich wojen europejskich przekształcił się w filar bezpieczeństwa kontynentu. Zdaniem autora, państwa należące do Trójkąta Weimarskiego powinny być przykładem w jaki sposób zmniejszyć różnice pomiędzy Europą Środkową a Europą Zachodnią w standardzie życia, zlikwidować lukę techniczno-cywilizacyjną co zapewni pokój i stabilność na całym kontynencie europejskim. Dziś w stosunkach między sojusznikami należy szukać szans w zakresie tworzenia i rozwoju EPBiO/WPBiO, a do wyzwań stojących przed państwami Trójkąta należy polityka wschodnia i polityka energetyczna.

\section{THE WEIMAR TRIANGLE BETWEEN 1991-1999 AND ITS IMPORTANCE FOR THE EUROPEAN SECURITY}

\begin{abstract}
The aim of the article is to analyze the Weimar Triangle's influence on the European security, focusing on the Polish-German and French-German relations, as they play a key role in forming a geostrategic and geopolitical structure in the European context. The way in which the European Union's member states cooperated with Poland is a symbol of reconciliation for those three great nations. The objective of this initiative was to transform an area of the bygone fierce European wars into a pillar of the continent's security. According to the author, the Weimar Triangle may serve as a perfect example of how the differences between the Central and Western Europe in terms of the standards of living could be reduced and how the technological and civilizational gulf could be neutralized in order to guarantee peace and stability in the whole of Europe. Nowadays, the foundation and development of ESDP/CSDP is a chance for good inter-ally relations, while the most serious challenges for the Triangle's countries include dealing with both the eastern policy and energy policy.
\end{abstract}


